\title{
TINJAUAN YURIDIS TERHADAP PERANAN PEMERINTAH DALAM PELAKSANAAN REHABILITASI HUTAN MANGGROVE
}

\author{
Armiwal $^{(1)}$, Suhaibah ${ }^{(2)}$ \\ ${ }^{1}$ Program Studi Sosial Politik Fakultas Sosial Politik Universitas Iskandarmuda \\ ${ }^{2}$ Program Studi Ilmu Hukum Fakultas Hukum Universitas Jabal Ghafur.
}

\begin{abstract}
ABSTRAK
Dalam Pasal 6 Undang-Undang Nomor 5 Tahun 1990 Tentang Konservasi Sumber Daya Alam Hayati dan Ekosistemnya bahwa "sistem penyangga kehidupan merupakan satu proses alami dari berbagai unsur hayati dan nonhayati yang menjamin kelangsungan kehidupan makhluk". Pasal 43 Ayat (1) Undang-Undang Nomor 41 Tahun 1999 yang menyatakan "bahwa setiap orang yang memiliki, mengelola, dan atau memanfaatkan hutan yang kritis atau tidak produktif, wajib melaksanakan rehabilitasi hutan untuk tujuan perlindungan dan konservasi". Hal tersebut dapat dilakukan dengan di dampingi oleh Lembaga Swadaya Masyarakat yang bergerak di bidang kehutanan dan di fasilitasi oleh Pemerintah Provinsi. Hasil hutan berupa kayu maupun hasil hutan ikutan dapat diekspor ke luar negeri, sehingga mendatangk:an devisa bagi negara. Ditinjau dari segi kepentingan manusia yang dapat merasakan manfaat hutan secara tidak langsung dapat dibagi dua, yaitu: manusia sebagai individu (butir a sampai g) dan manusia sebagai warga negara. Manfaat hutan tersebut diperoleh apabila hutan terjamin eksistensinya sehingga dapat berfungsi secara optimal. Fungsi-fungsi ekologi, ekonomi dan sosial dari hutan akan memberikan peranan nyata apabila pengelolaan sumber daya alam berupa hutan seiring dengan upaya pelestarian guna mewujudkan pembangunan nasional berkelanjutan.
\end{abstract}

Kata Kunci: Peran Pemerintah Dalam Rehabilitasi Hutan.

\section{PENDAHULUAN}

Hutan sebagai paru-paru dunia tidak hanya dimanfaatkan manusia sebagai dasar dalam memenuhi kebutuhan hidup seperti pemanfaatan kayu sabagai bahan bakar dan pembangunan tempat kediaman manusia, namun lebih dari itu hutan juga dimanfaatkan manusia sebagai usaha untuk mencegah terjadinya bencana yang dapat menyebabkan bahaya bagi kelangsungan kehidupan umat manusia di muka bumi ini.

$$
\text { Dalam upaya menjaga dan }
$$

melestarikan fungsi hutan sebagai penyangga kehidupan umat manusia dibumi ini tidak hanya dilaksanakan oleh pemerintah sebagai pengambil kebijakan pada suatu negara atau daerah, tetapi juga peran serta masyarakat setempat untuk dapat menjaga kelestarian fungsi hutan tersebut tentunya sangat diharapkan.
Dalam Pasal 6 Undang-Undang Nomor 5 Tahun 1990 Tentang Konservasi Sumber Daya Alam Hayati dan Ekosistemnya dinyatakan bahwa "sistem penyangga kehidupan merupakan satu proses alami dari berbagai unsur hayati dan nonhayati yang menjamin kelangsungan kehidupan makhluk". Sebagai upaya menjaga ekosistem hutan sebagaimana dinyatakan di atas pemerintah Indonesia mengeluarkan aturan berupa UndangUndang Nomor 41 Tahun 1999 Tentang Kehutanan yang di dalam Pasal 4 disebutkan bahwa :

Penyelenggaraan kehutanan bertujuan untuk sebesar-besar kemakmuran rakyat yang berkeadilan dan berkelanjutan dengan:

1. Menjamin keberadaan hutan dengan luasan yang cukup dan sebaran yang proporsional; 
2. Mengoptimalkan aneka fungsi hutan yang meliputi fungsi konservasi, fungsi lindung, dan fungsi produksi untuk mencapai manfaat

3. lingkungan, sosial, budaya, dan ekonomi, yang seimbang dan lestari;

4. meningkatkan daya dukung daerah aliran sungai;

5. meningkatkan kemampuan untuk mengembangkan kapasitas dan keberdayaan masyarakat secara partisipatif, berkeadilan, dan berwawasan lingkungan sehingga mampu menciptakan ketahanan sosial dan ekonomi serta ketahanan terhadap akibat perubahan ekstemal; dan menjamin distribusi manfaat yang berkeadilan dan berkelanjutan.

Selanjutnya dalam Pasal 2 UndangUndang Nomor 41 Tahun 1999 dinyatakan bahwa penyelenggaraan kehutanan berasaskan manfaat dan lestari, kerakyatan, keadilan, kebersamaan, keterbukaan, dan keterpaduan. Penyelenggaraan pengelolaan tersebut merupakan tanggung jawab pemerintah sebagai badan yang mengambil kebijakan di suatu daerah. selain itu dalam Pasal 43 Ayat (1) dan (2) Undang-Undang Nomor 41 Tahun 1999 dinyatakan bahwa:

1) Setiap orang yang memiliki, mengelola, dan atau memanfaatkan hutan yang kritis atau tidak produktif, wajib melaksanakan rehabilitasi hutan untuk tujuan perlindungan dan konservasi.

2) Dalam pelaksanaan rehabilitasi sebagaimana dimaksud pada ayat (1) setiap orang dapar rneminta pendampingen, pelaysnan dan dukungan kepada lembaga swadaya masyarakat, pihak lain atau pemerintah.

Salah satu jenis hutan yang dikelola oleh pemerintah adalah hutan mangrove, pentingnya pengelolaan hutan mangrove bertujuan untuk menjaga garis bibir pantai dari terjadinya abrasi, tempat berpijahnya aneka biota laut dan tempat berlindung dan berkembangbiak berbagai jenis burung, mamalia, reptil, dan serangga sebagai pengatur iklim mikro.
Dalam Pasal 43 Ayat (1) UndangUndang Nomor 41 Tahun 1999 yang menyatakan "bahwa setiap orang yang memiliki, mengelola, dan atau memanfaatkan hutan yang kritis atau tidak produktif, wajib melaksanakan rehabilitasi hutan untuk tujuan perlindungan dan konservasi". Hal tersebut dapat dilakukan dengan di dampingi oleh Lembaga Swadaya Masyarakat yang bergerak di bidang kehutanan dan di fasilitasi oleh Pemerintah Provinsi. Mengenai hal ini juga disebutkan dalam Pasal 25 Ayat (1), (2), (3) Qanun Provinsi Nanggroe Aceh Darussalam Nomor 14 Tahun 2002 Tentang Kehutanan Provinsi Nanggroe Aceh Darussalam. Selanjutnya dalam ketentuan Pasal 24 Ayat (2) Qanun Provinsi Nanggroe Aceh Darussalam Nomor 14 Tahun 2002 disebutkan bahwa :

Rehabilitasi hutan dan lahan diselenggarakan melalui kegiatan :

a. reboisasi;

b. penghijauan;

c. pemeliharaan;

d. pengayaan tanaman; atau

e. penerapan teknik konservasi tanah secara vegetatif dan sipil teknis, pada lahan kritis dan tidak produktif.

Hutan mangrove di Kabupaten Aceh Besar mengalami kerusakan akibat bencana gempa dan tsunami pada tahun 2004 yang diperkirakan mencapai sekitar 17,746 hektar. Kerusakan berat hutan mangrove di Kabupaten Aceh Besar terjadi di Kecamatan Mesjid Raya dan Kecamatan Baitussalam yang diperkirakan mencapai 140 hektar.namun proses rehabilitasi hutan mangrove di daerah tersebut belum dilaksanakan dengan baik oleh pemerintah, hal ini terlihat dengan masih kurangnya pohon bakau di pantai Aceh Besar, padahal daerah ini merupakan kawasan yang paling parah mengalami kerusakan hutan mangrove yang diakibatkan oleh bencana tsunami dan juga oleh berbagai faktor lainnya yang dapat menyebabkan rusaknya kawasan hutan mangrove. 


\section{KERANGKA PEMIKIRAN DAN TINJAUAN KEPUSTAKAAN}

Kata hutan sendiri merupakan terjemahan dari kata bos (Belanda) dan forest (lnggris). Forest merupakan dataran tanah yang bergelombang, dan dapat dikembangkan untuk kepentingan di luar kehutanan, seperti pariwisata. Di dalam hukum lnggris kuno, forest (hutan) adalah suatu daerah tertentu yang tanahnya ditumbuhi pepohonan, tempat hidup binatang buas dan burung-burung hutan. Di samping itu hutan juga dijadikan tempat pemburuan, tempat istirahat, dan tempat bersenang-senang bagi raja dan pegawai-pegawainya, namun dalam perkem-bangan selanjutnya ciri khas ini menjadi hilang.

Menurut Alam Setia Zain dalam bukunya Hukum Lingkungan Konservasi Hutan yang dimaksud dengan hutan adalah :"Suatu lapangan pertumbuhan pohon-pohon yang secara keseluruhan merupakan persekutuan hidup alam hayati beserta alam lingkungannya, dan ditetapkan oleh pemerintah sebagai hutan. Artinya, hutan suatu areal yang cukup luas, di dalamnya bertumbuhan kayu, bambu dan/atau palem, bersama-sama dengan tanahnya, beserta segala isinya, baik berupa nabati maupun hewani, yang secara keseluruhan merupakan persekutuan hidup yang mempunyai kemampuan untuk memberikan manfaat-manfaat lainnya secara lestari".

Pengertian hutan menurut Alam Setia Zain tersebut diatas, juga hampir sama dengan yang di kemukakan oleh Dengler. Menurut Dengler yang diartikan dengan hutan, adalah:"Sejumlah pepohonan yang tumbuh pada lapangan yang cukup luas, sehingga suhu, kelembapan, cahaya, angin, dan sebagainya tidak lagi menentukan lingkungannya, akan tetapi dipengaruhi oleh tumbuh- tumbuhan/ pepohonan barn asalkan tumbuh pada tempat yang cukup luas dan tumbuhnya cukup rapat (horizontal dan vertikal)".
Sedangkan pengertian hutan di dalam Pasal 1 ayat (2) Undang-Undang Nomor 41 Tahun 1999 tentang Kehutanan adalah suatu kesatuan ekosistem berupa hamparan lahan berisi sumber daya alam hayati yang didominasi pepohonan dalam persekutuan alam lingkungannya, yang satu dengan lainnya tidak dapat dipisahkan. Dari beberapa pengertian hutan tersebut diatas, ada empat unsur yang terkandung di dalamnya, yaitu :

1. Unsur lapangan yang cukup luas (minimal lf.c hektar), yang disebut tanah hutan;

2. Unsur pohon (Kayu, bambu, palem) flora dan fauna;

3. Unsur lingkungan; dan

4. Unsur penetapan pemerintah.

1. Fungsi Hutan

Hutan berdasarkan fungsinya adalah penggolongan hutan yang didasarkan pada kegunaannya. Berdasarkan Undang-Undang Nomor 41 Tahun 1999 tentang Kehutanan, hutan berdasarkan fungsinya digolongkan menjadi tiga macam, yaitu sebagaimana disebutkan dalam Pasal 6 sebagai berikut:

1) Hutan mempunyai tiga fungsi, yaitu:
a. Fungsi konservasi, b. fungsi lindung, dan

b. Fungsi produksi.

2) Pemerintah menetapkan hutan berdasarkan fungsi pokok sebagai berikut:
a. hutan konservasi,
b. hutan lindung,
c. hutan produksi.

Berdasarkan uraian tersebut diatas menjadi jelas bahwa Undang-Undang Nomor 41 Tahun 1999 tentang Kehutanan, menggolongkan hutan berdasarkan fungsinya mejadi tiga macam, yaitu hutan konservasi, hutan lindung, dan hutan produksi.

a. Hutan Konservasi

Hutan konservasi adalah kawasan hutan dengan ciri khas tertentu yang mempunyai fungsi pokok pengawetan 
keanekaragaman tumbuhan dan satwa beserta ekosistemnya. Hutan konservasi terdiri dari tiga macam, yaitu kawasan hutan suaka alam, kawasan hutan pelestarian alam, dan taman buru. Kawasan hutan suaka alam adalah hutan dengan ciri khas tertentu yang mempunyai fungsi pokok sebagai kawasan pengawetan keanekaragaman tumbuhan dan satwa serta ekosistemnya, yang juga berfungsi sebagai wilayah sistem penyangga kehidupan. Kawasan hutan pelestarian alam adalah hutan dengan ciri khas tertentu yang mempunyai fungsi pokok perlindungan sistem penyangga kehidupan pengawetan keanekaragaman jenis tumbuhan dan satwa, serta pemanfaatan secara lestari sumberdaya alam hayati dan ekosistemnya. Taman buru adalah kawasan hutan yang ditetapkan sebagai ternpat wisata berburu.

b. Hutan Lindung

Hutan lindung adalah kawasan hutan yang mempunyai fungsi pokok sebagai perlindungan sistem penyangga kehidupan untuk mengatur tata air, mencegah banjir, mengendalikan erosi, mencegah intrusi (penerobosan) air laut, dan memelihara kesuburan tanah.

Kawasan hutan, terutama hutan lindung, adalah kawasan resapan air yang memiliki curah hujan tinggi dengan struk:tur tanah yang mudah meresapkan air dan bentuk geomorfologi yang mampu meresapkan air hujan secara besar-besaran. Di sini sistem hidrologi berlaku, artinya hutan merupakan gudang penyimpanan air dan tempat menyerapnya air hujan ataupun embun. Pada umumnya, di daerah hutan terutama di daerah dataran tinggi dan pegunungan lembab, kabut mengembun pada daun dan dahan pohon yang disebut intersepsi horizontal. Air yang mengembun akan menetes ke tanah dan menambah besarnya aliran yang meresap ke dalam tanah. Pada akhirnya, aliran air di bawah permukaan tanah bertambali dan menghasilkan air jernih yang akan dialirkan ke sungai-sungai yang memiliki mata air secara teratur di dalam hutan daerah aliran sungai.

c. Rutan produksi

Hutan yang berfungsi produksi (hutan Produksi) adalah kawasan hutan yang ditumbuhi oleh pepohonan keras yang perkembangannya selalu diusahakan dan dikhususkan untuk dipungut hasilnya, baik berupa kayu- kayuan maupun hasil-hasil sampingan lainnya, seperti getah, damar, akar, dan lain-lainnya. Hasil produksi tersebut digunakan untuk memenuhi keperluan masyarakat dan untuk membangun industri serta ekspor, tetapi masih tetap memperhatikan fungsi ekologisnya.

Fungsi utama hutan produksi adalah untuk dikelola dan dimanfaatkan secara optimal, sebagai salah satu sumber pendapatan negara dalam rangka peningkatan perekonomian nasional. Rutan produksi berfungsi penting bagi penyediaan bahan baku industri yang beraneka ragam dari olahan hasil hutan.

Fungsi hutan produksi juga memiliki peran yang penting di bidang perekonomian karena produksi hasil hutan dapat meningkatkan pembangunan ekonomi nasional dan kemakmuran rakyat.

Jadi, hutan mempunyai fungsi yang menguasai hajat hidup orang banyak, antara lain sebagai berikut:

1. Mengatur tata air, mencegah bahaya banjir, mencegah erosi, dan memelihara kesuburan tanah.

2. Memenuhi produksi hasil hutan untuk keperluan masyarakat pada umumnya dan khususnya untuk keperluan pembangunan, industri, dan ekspor.

3. Membantu pembangunan ekonomi nasional pada umumnya dan mendorong industri hasil hutan pada khususnya,

4. Melindungi suasana iklim dan memberi daya pengaruh yang baik.

5. Memberi keindahan alam pada umumnya dan khususnya dalam bentuk Cagar Alam, Suaka Margasatwa, Taman Wisata, dan Taman Buru bagi kepentingan ilmu pengetahuan 
pendidikan, kebudayaan, dan pariwisata.

6. Merupakan salah satu unsur basis strategis pertahanan nasional.

2. Manfaat Hutan

Hutan mempunyai kedudukan dan peranan yang sangat penting dalam menunjang pembangunan bangsa dan negara. Hal ini disebabkan hutan dapat memberikan manfaat yang sebesarbesarnya bagi kemakmuran dan kesejahteraan rakyat.

Menurut Ngadung ada tiga manfaat hutan, yaitu (1) langsung, (2) tidak langsung, dan (3) manfaat lainnya. Sedangkan Salim HS, mengklasifikasikan manfaat hutan menjadi dua, yaitu: (1) manfaat langsung, dan (2) manfaat tidak langsung. Alasannya, bahwa manfaat lainnya yang dikemukakan oleh Ngadung lebih tepat digolongkan dalam manfaat tidak langsung.

1. Manfaat Langsung

Manfaat langsung adalah manfaat yang dapat dirasakan langsung dan dinikmati secara langsung oleh masyarakat. Yaitu masyarakat dapat menggunakan dan mamanfaatkan hasil hutan, antara lain kayu yang merupakan hasil utama hutan, serta berbagai hasil hutan ikutan, seperti rotan, getah, buah-buahan, madu, dan lain-lain.

Pada mulanya kayu digunakan hanya sebagai bahan bakar, baik untuk memanaskan diri (di daerah bermusim dingin) maupun untuk menanak/memasak makanan kemudian kayu digunakan sebagai bahan bangunan, alat-alat rumah tangga, pembuatan kapal, perahu, dan lain-lain, dan dapat dikatakan bahwa kayu sangat dibutuhkan oleh umat manusia.

2. Manfaat Tidak Langsung

Manfaat tidak langsung adalah manfaat yang tak langsung dinikmati oleh masyarakat, akan tetapi yang dapat dirasakan adalah keberadaan hutan itu sendiri. Ada delapan manfaat hutan secara tidak langsung, yaitu sebagai berikut:

a. Dapat mengatur tata air.
Hutan dapat mengatur dan meninggikan debit air pada musim kemarau, dan mencegah terjadinya debit air yang berlebihan pada musim hujan. Hal ini disebabkan dalam hutan terdapat air retensi, yaitu air yang masuk kedalam tanah, dan sebagian bertahan dalam saluran-saluran kecil yang terdapat dalam tanah.

b. Dapat mencegah terjadinya erosi.

Hutan dapat mencegah dan menghambat mengalirnya air karena adanya akar-akar kayu dan akar tumbuh-tumbuhan.

c. Dapat memberikan manfaat terhadap kesehatan.

Manusia memrlukan zat asam (02). Di hutan dan di sekitarnya zat asam adalah sangat bersih dibandingkan dengan tempat-tempat yang lain. Dalam hutan juga terdapat ozon (udara murni) dan air murni yang sangat diperlukan manusia.

d. Dapat memberikan rasa keindahan.

Hutan dapat memberikan rasa keindahan pada menusia karena di dalam hutan itu seseorang dapat menghilangkan tekanan mental dan stress.

e. Dapat memberikan manfaat di sektor pariwisata.

Daerah-daerah yang mempunyai hutan yang baik dan lestari akan dikunjungi wisatawan, baik mancanegara maupun domestik untuk sekedar rekreasi dan untuk berburu.

f. Dapat memberikan manfaat dalarn bidang pertahanan keamanan.

Sejak zaman dahulu sampai sekarang hutan mempunyai peranan yang sangat penting dalam bidang pertahanan keamanan, karena dapat untuk kamuflase bagi pasukan sendiri dan menjadi hambatan bagi pasukan lawan.

g. Dapat menampung tenaga kerja

Setiap perusahaan yang mengembangk:an usahanya di bidang kehutanan pasti memerlukan tenaga kerja dalam jumlah yang cukup besar 
untuk melakukan penanaman, penebangan, pengolahan, dan .pemasaran hasil hutan, sehingga dapat menurunkan angk:a pengangguran.

h. Dapat menambah devisa negara.

Hasil hutan berupa kayu maupun hasil hutan ikutan dapat diekspor ke luar negeri, sehingga mendatangk:an devisa bagi negara. Ditinjau dari segi kepentingan manusia yang dapat merasakan manfaat hutan secara tidak langsung dapat dibagi dua, yaitu: manusia sebagai individu (butir a sampai g) dan manusia sebagai warga negara .

\section{Berbagai Kebijakan Di Bidang Kehutanan \\ Bersumber \\ dari amanat}

Undang-Undang Dasar 1945, barbagai peraturan perundang-undangan nasional yang mengatur pemanfaatan hutan, bumi, air dan ruang angkasa, dijadikan pedoman dasar untuk mewujudkan tujuan nasional dalam pembangunan berkelanjutan. Undang-Undang Dasar 1945, memberikan dasar hukum yang kuat bagi pengelolaan sumber daya alam. Hal ini sebagaimana disebutkan dalam Pasal 33 ayat (3) Undang-Undang Dasar 1945, yang berbunyi "Bumi dan air dan kekayaan alam yang terkandung didalamnya dikuasai oleh Negara dan dipergunakan untuk sebesar-besar kemakmuran rakyat".

Hutan sebagai bagian dari sumber daya alam, sejak dimulainya pembangunan secara bertahap telah diletakkan landasan yang kokoh sebagai prinsip dasar untuk di pedomanibagi pembangunan hutan lestari.

Dengan demikian Pasal 33 ayat 3 Undang-Undang Dasar 1945 merupakan dasar hukum utama dalam pengelolaan sumber daya alam, termasuk juga hutan didalamnya, karena hutan juga merupakan bagian dari sumber daya alam. Kemudian berdasarkan Undang-Undang Dasar 1945, selanjutnya dijabarkan dalam bentuk Undang-Undang,
Sejak bangsa Indonesia merdeka pada tanggal 17 Agustus 1945 sampai sekarang temyata Pemerintah dengan persetujuan DPR telah berhasil menetapkan peraturan perundang-undangan yang menjadi dasar hukum dalam bidang kehutanan. Peraturan perundang-undangan yang dimaksud, adalah seperti berikut ini:

1. Undang-Undang Nomor 5 Tahun 1960 tentang Undang-Undang Pokok Agaria.

2. Undang-Undang Nomor 5 Tahun 1967 tentang ketentuan-Ketentuan Pokok Kehutanan.

3. Undang-Undang Nomor 4 Tahun 1982 tentang Ketentuan-Ketentuan Pokok Pengelolaan Lingkungan Hidup.

4. Undang-Undang Nomor 5 Tahun 1990 tentang Konservasi Sumber Daya Alam dan Ekositemnya.

5. Undang-Undang Nomor 23 Tahun 1997 tentang Pengelolaan Lingkungan Hidup.

6. Undang-Undang Nomor 41 Tahun 1999 tentang Kehutanan.

Dari keenam peraturan perundangundangan tersebut maka ada dua Undang-Undang yang telah dicabut, yaitu Undang-Undang Nomor 5 Tahun 1967 dan Undnag-Undang Nomor 4 Tahun 1982. sedangkan yang masih berlaku adalah Undang-Undang Nomor 5 Tahun 1960, Undang-Undang Nomor 23 Tahun 1997, dan Undang-Undang Nomor 41 tahun 1999. Keempat peraturan perundang- undangan yang masih berlaku tersebut merupakan dasar hukum dalam pelaksanaan kegiatan kehutanan di Indonesia. Tetapi dari keempat peraturan tersebut hanya ada dua Undnag-Undang yang khusus mengatur tentang keutanan, yaitu Undnag-Undang Nomor 5 Tahun 1990 dan Undnag-Undang Nomor 41 Tahun 1999, sedangkan Undnag-Undang Nomor 5 Tahun 1960 tentang UUPA dan Undnag-Undang Nomor 23 Tahun 1997 merupakan Undnag-Undang yang bersifat umum.

Masalah kehutanan sebelumnya diatur dalam Undang-Undang Nomor 5 tahun 1967 tentang Ketentuan-Ketentuan Pokok 
Kehutanan. Sesuai dengan perkembangan, penerapan Undang-Undang Nomor 5 Tahun 1967 (Lembaran Negara Tahun 1967 Nomor 8) dianggap sudah tidak sesuai lagi dengan prinsip penguasaan dan pengurusan hutan, dan tuntutan perkembangan keadaan, sehingga ditetapkan penggantinya berupa Undang-Undang Nomor 41 Tahun 1999 tentang Kehutanan.

Ketentuan yang terpenting dalam Undang-Undang Nomor 41 ini dimuat dalam beberapa pasal, yaitu seperti dalam Pasal 1 butir 2, hutan diartikan sebagai suatu kesatuan ekosistem berupa hamparan lahan berisi sumbar daya alam hayati yang didominasi pepohonan dalam persekutuan alam lingkungannya, yang satu dengan lainnya tidak dapat dipisahkan.

Sesuai dengan pasal 33 ayat (3) Undang-Undang Dasar 1945 UndangUndang Nomor 41 Tahun 1999 ini juga mengatur tentang perencanaan, peruntukan, penyediaan, dan penggunaan hutan sesuai dengan fungsinya yaitu baik dari fungsi konservasi, fungsi lindung maupun fungsi produksi.

Selain undang-undang sebagaimana disebutkan diatas, kebijakan-kebijakan lainnya di bidang kehutanan, yaitu sebagai berikut:

a. Undang-Undang Nomor 19 Tahun 2004 tentang Penetapan Peraturan Pemerintah Pengganti Undang-Undang Nomor 1 Tahun 2004 tentang Perubahan atas Undang-Undang Nomor 41 Tahun 1999 tentang Kehutanan.

b. Peraturan Pemerintah Pengganti Undang-Undang Nomor 1 Tahun 2004 tentang Perubahan atas Undang-Undang Nomor 41 Tahun 2004.

c. Peraturan Pemerintah Nomor 34 Tahun 2002 tentang Tata Hutan dan Penyusunan Rencana Pengelolaan Hutan, Pemanfaatan Hutan dan Penggunaan Kawasan Rutan.

d. Peraturan Pemerintah Nomor 6 Tahun 2007 tentang Tata Rutan dan
Penyusunan Rencana Pengelolaan Rutan.

e. Peraturan Pemerintah Nomor 45 Tahun 2004 tentang Perlindungan Rutan.

f. Peraturan Pemerintah Nomor 44 Tahun 2004 Perencanaan Kehutanan.

g. Instruksi Presiden Nomor 4 Tahun 2005 tentang Pemberantasan Penebangan Kayu Secara Iegal di Kawasan Rutan dan Peredarannya di Seluruh Wilayah Republik Indonesia

h. Instuksi Menteri Dalam Negeri Nomor 3 Tahun 2005 tentang Pemberantasan Penebangan Kayu Secara Illegal di Kawasan Rutan dan Peredarannya di Seluruh Wilayah Republik Indonesia.

i. Keputusan Bersama Menteri Perhubungan Menteri Kehutanan dan Menteri Perindustrian dan Perdagangan Nomor KM 3 Tahun 2003 Nomor 22/KPTS-II/2003, Nomor 33/MPP/Kep/1/2003 tentang Pengawasan pengangkutan Kayu Melalui Pelabuhan.

\section{Tata Cara Pengelolaan Hutan}

Pengelolaan merupakan suatu usaha yang di dalamnya meliputi beberapa aspek, seperti perencanaan, organisasi pelaksanaan, implementasi, monitoring, dan evaluasi yang setiap fungsi saling berkaitan dan merupakan satu kesatuan yang saling mempengaruhi. Akhirnya, pengelolaan hutan bertujuan untuk menghasilkan sesuatu yang dikelola, sedangkan hutan berisi berbagai kehidupan yang saling ketergantungan. Dengan demikian, aspek pengelolaan hutan dapat dikatakan sebagai usaha yang meliputi beberapa bidang ilmu yang saling mendukung, seperti ilmu tanah, agronomi, perlindungan tanaman, sosial ekonomi, dan lingkungan, bahkan saat ini mencakup bidang komputerisasi. Ilmu yang terakhir ini sangat mendukung dengan semakin banyaknya tuntutan terhadap fungsi hutan, juga dalam keakuratan informasi.

Makna pengelolaan terhadap potensi sumber daya alam berupa hutan, terkandung 
pengertian yang berdimensi luas dan bermulti aspek. Di antara berbagai persepsi yang ada maka, arti pengelolaan hutan yang diterima secara obyektif, dipetik dari falsafah logikal lahirnya idealisme pembangunan hutan lestari yaitu:

a. Pengelolaan hutan, adalah rangkaian dari upaya pemanfaatan sumber daya alam hayati serta ekosistemnya;

b. Pengelolaan hutan, merupakan bagian dari kegiatan pembangunan nasional secara bartahap dan terencana;

c. Pengelolaan hutan, adalah rangkaian dari kegiatan pelestarian sumber daya alam karunia Tuhan Yang Maha Esa;

d. Pengelolaan hutan, dilaksanakan secara optimal dan lestari dalam rangka pembangunan, industri dan ekspor;

e. Pengelolaan hutan merupakan amanat penderiataan rakyat yang tidak boleh ditunda-tunda dalam rangka pembangunan ekonomi nasional untuk mewujudkan kesejahteraan rakyat;

f. Pengelolaan hutan, ditujukan untuk memenuhi keperluan masyarakat pada

g. Pengelolaan hutan, dilakukan untuk memenuhi kepentingan ilmu pengetahuan, pendidikan, kebudayaan dan kepariwisataan.

Bardasarkan Pasal 21

Undang-Undang Nomor 41 Tahun 1999 tentang Kehutanan, disebutkan bahwa pengelolaan hutan meliputi:

a. Tata hutan dan penyusunan rencana pengelolaan hutan,

b. pemanfaatan hutan dan penggunaan kawasan hutan,

c. Rehabilitasi dan reklamasi hutan, dan

d. Perlindungan hutan dan konservasi alam.

Mengingat kawasan hutan sedemikian luas dan terkait dengan pihak-pihak lain serta stoke holders, maka pengawasan secara langsung terhadap semua pihak merupakan pekerjaan yang tidak mungkin dapat dilakukan. Untuk memecahkan permasalahan tersebut, maka kebijakan pengelolaan hutan harus ditujukan untuk membangun kesadaran bersama akan pentingnya kelestarian fungsi hutan. Pengelolaan hutan tersebut membutuhkan dukungan berupa perangkat pengelolaan yang mampu memadukan berbagai informasi yang komplek, sehingga dapat mendukung pengambilan keputusan yang tepat. Dicontohkan adanya program SIG (Sistem Informasi Geografi) dan Sistem Informasi Sumber Daya Hutan dengan Pengolahan Data Elektronik (PDE), di mana kedua sistem tersebut disebut Sistem Informasi Kebumian. Dalam pemetaan hutan, SIG akan banyak mendukung keakuratan luas hutan. SIG merupakan sistem pendukung dalam penganalisaan data yang dibantu oleh PDE sebagai informasi tentang gambaran kondisi hutan akan menghasilkan suatu keputusan.

Menurut Alam Setia Zain, bentuk pengelolaan hutan dibagi ke dalam dua bagian, yaitu:

1. Pengelolaan hutan negara yaitu, suatu bentuk kegiatan usaha yang dilaksanakan Pemerintah atau Badan Hukum yang ditunjuk dalam rangka memperoleh manfaat hutan dan hasil hutan di kawasan hutan negara, berdasarkan peraturan-peraturan perundang-undangan yang berlaku.

2. Pengelolaan hutan rakyat yaitu, suatu bentuk kegiatan usaha yang dilakukan Orang atau Badan Hukum dalam rangka memperoleh manfaat hutan dan hasil hutan, di atas tanah milik atau hale lainnya, bardasarkan peraturan perundang-undangan.

Sendi pelaksanaan pengelolaan hutan dideklarasikan ke dalam 3 asas konvensi intemasional yang di terapkan. Ketiaga aspek penting dalam rangka pemanfaatan hutan adalah:

a. Asas Kesejahteraan Sosial, ialah asas keutamaan yang menitikberatkan perhatian kepada realitas kesejahteraan di sektor kehidupan masyarakat bawah. Dalam pengelolaan hutan, penduduk asli dan anggota masyarakat yang bermukim di dalam dan di sekitar 
hutan, memiliki peranan penting untuk melestarikan hutan. Mereka mempunyai pengetahuan, pengalaman serta kebiasaan tradisional yang bermanfaat bagi pengelolaan dan pelestarian hutan. Masyarakat ini perlu diberikan peranan untuk berpartisipasi aktif mewujudkan pembangunan hutan berkelanjutan. Mereka berhak mendapatkan sesuatu kehidupan yang baik dan produktif serta harmonis dengan lingkungan pemukimannya, Salah satu upaya dilakukan dalam rangka peningkatan kesejahteraan bagi masyarakat desa hutan adalah, upaya peningkatan kesadaran sosial dan partisipasi melalui kegiatan penyuluhan.

b. Asas Keuntungan Ekonomi, atau disebut juga asas profitabilitas yaitu, suatu prinsip pengelolaan hutan yang berorientasi kepada perolehan laba dalam ragka peningkatan pendapatan dan kemajuan usaha. Peranan hutan produksi di dalam menunjang kekuatan ekonomi nasional telah terbukti sebagai kekuatan penting yang menempati posisi kedua penghasil devisa setelah minyak dan gas bumi. Bahkan, dari sejumlah investasi besar atas peranan dan keikutsertaan pihak swasta di sector pengelolaan hutan, telah berada di urutan paling atas dari semua ekspor non migas.

c. Asas Kelestarian Lingkungan, atau disebut prinsip ekologi yaitu, suatu prinsip pengelolaan hutan yang berorientasi kepada usaha pemanfaatan hutan secara lestari dengan sistem silvikultur. Sistem silvikultur adalah, proses penanaman, pemeliharaan, penebangan, penggantian suatu tegakan hutan untuk menghasilkan produksi kayu, atau hasil hutan lainnya dalam bentuk tertentu. Penerapan sistem silvikultur di kawasan hutan produksi dilakukan 3 cara yaitu: Tebang Pilih Tanam (TPTI), Tebang Habis dengan Permudaan Alam (TPHA) dan Tebang
Habis dengan Pennudaan Buatan THPB).

\section{Tanggung Jawab Pengelolaan Hutan}

Pemanfaatan hutan merupakan bagian dari pengelolaan hutan yang bertujuan untuk diperolehnya manfaat basil dan jasa hutan yang maksimum dan lestari. Hal ini, sebagaimana di sebutkan dalam Pasal 2 Peraturan Pemerintah Nomor 6 tahun 2007 tentang Tata Rutan dan Penyusunan Rencana Pengelolaan Rutan, serta Pemanfaatan Rutan, yang berbunyi bahwa "tata hutan dan penyusunan rencana pengelolaan utan serta pemanfaatan hutan merupakan bagian dari pengelolaan hutan".

Dalam Pasal 21 Undang-Undang Nomor 41 Tahun 1999 tentang Kehutanan, juga disebutkan tentang pengelolaan hutan. Menurut pasal tersebut kegiatan pengelolaan hutan meliputi:

1. Tata hutan dan penyusunan rencana pengelolaan hutan,

2. Pemanfaatan hutan dan penggunaan kawasan hutan,

3. Rehabilitasi dan reklamasi hutan, dan

4. Perlindungan hutan dan konservasi alam.

Pengelolaan hutan pada dasarnya menjadi kewenangan Pemerintah dan atau Pemerintah Daerah. Mengingat berbagai kekhasan daerah serta kondisi sosial dan lingkungan yang sangat berkait dengan kelestarian hutan dan kepentingan masyarakat luas yang membutuhkan kemampuan pengelolaan secara khusus, maka pelaksanaan pengelolaan hutan di wilayah tertentu dapat dilimpahkan kepada BUMN yang bergerak di bidang kehutanan, baik berbentuk perusahaan umum (Perum), perusahaan jawatan (Perjan), maupun perusahaan perseroan (Persero), yang pembinaannya di bawah Menteri. Untuk mewujudkan pengelolaan hutan yang lestari dibutuhkan lembaga-lembaga penunjang antara lain lembaga keuangan yang mendukung pembangunan kehutanan, lembaga penelitian dan pengembangan, 
lembaga pendidikan dan latihan, serta lembaga penyuluhan.

Pengelolaan hutan merupakan usaha untuk mewujudkan pengelolaan hutan lestari berdasar tata hutan, rencana pengelolaan, pemanfaatan hutan, rehabilitasi hutan, perlindungan hutan dan konservasi. Untuk mewujudkan pengelolaan hutan lestari maka seluruh kawasan hutan terbagi ke dalam KPH. KPH menjadi bagian dari penguatan sistem pengurusan hutan nasional, propinsi dan kabupaten/kota. KPH dikelola oleh suatu Unit Organisasi KPH.

Pemanfaatan hutan yang merupakan bagian dari pengelolaan hutan dilaksanakan berdasarkan rencana pengelolaan hutan. Pemanfaatan hutan dilakukan oleh BUMN/BUMD/BUMS wajib bekerjasama dengan Koperasi atau Kelompok Masyarakat Setempat. Pemanfaatan hutan dapat dilakukan pada semua kawasan hutan kecuali pada hutan cagar alam, dan pada zona inti serta zona rimba taman nasional.

1. Badan Usaha Milik Negara

Pemerintah dapat melimpahkan penyelenggaraan pengelolaan hutan kepada Badan Usaha Milik Negara (BUMN) bidang kehutanan. Direksi BUMN bidang kehutanan yang mendapat pelimpahan penyelenggaraan pengelolaan hutan bertindak selaku kepala KPH (Kesatuan Pengelolaan Hutan). Penyelenggaraan pengelolaan hutan oleh BUMN, tidak termasuk kewenangan Publik. Penyelenggaraan pengelolaan hutan oleh BUMN bidang kehutanan diatur dengan Peraturan Pemerintah tersendiri. Hal ini sebagaimana disebutkan dalam Pasal 4 Peraturan Pemerintah Nomor 6 tahun 2007 tentang Tata Hutan dan Penyusunan Rencana Pengelolaan Hutan, serta Pemanfaatan Hutan, yaitu:

1) Pemerintah dapat melimpahkan penyelenggaraan pengelolaan hutan kepada badan usaha milik Negara (BUMN) bidang kehutanan.

2) Direksi BUMN bidang kehutanan yang mendapat pelimpahan penyelenggaraan pengelolaan hutan sebagaimana dimaksud pada ayat (1), membentuk organisasi KPH dan menunjuk kepala KPH.

3) Penyelenggaraan pengelolaan hutan oleh BUMN, tidak termasuk kewenangan publik.

4) Penyelenggaraan pengelolaan hutan oleh BUMN bidang kehutanan sebagaimana dimaksud pada ayat (1) diatur dalam peraturan pemerintah tersendiri.

2. Badan Usaha Milik Swasta

Badan Usaha Swasta berkedudukan sebagai partner Pemerintah diarahkan untuk mencapai dan mewujudkan cita-cita dan tujuan pemanfaatan hutan secara lestari. Sebagai pengelola hutan, Badan Usaha Swasta diberi peranan dan tanggung jawab untuk melakukan usaha bersama bagi peningkatan kesejahteraan masyarakat dan tercapainya penerimaan keuangan negara dibidang pengusahaan hutan. Dalam kedudukannya selaku subyek hukum, maka setiap Badan Usaha Milik Swasta dipersamakan kedudukannya dengan manusiawi yakni, wajib tunduk dan mematuhi segala ketentuan- ketentuan hukum perundang-undangan nasional yang berlaku.

\section{Perorangan/Kelompok}

Sifat per orangan atau kelompok yang tidak berstatus Badan Hukum, juga memperoleh sedikit peluang untuk berperanserta sebagai partner bagi kegiatan pernungutan basil hutan. Keterbatasan pemberian izin usaha pengelolaan hutan bagi perorangan atau kelompok, khususnya di dalam kawasan hutan negara, merupakan realitas kebijakan dalam pelaksanaarinya Berbagai aspek pertimbangan untuk dijadikan dasar pembatasan usaha secara orang perorangan dalam pengelolaan hutan negara, terutama dititikberatkan pada: (a) aspek permodalan (b) aspek manajemen (c) aspek pelaksanaan (d) aspek bonafiditas usaha (e) aspek pemasaran dan (f) aspek pertanggung- jawaban usaha. 
4. Masyarakat Adat

Eksistensi masyarakat hukum adat yang diakui sepanjang kenyataannya masih ada, merupakan pendukung hak dan kewajiban di dalam proses pelaksanaan penegakan hukum. Sistem hukum adat yang pemah berlaku di lingkungan masyarakat adat, dinyatakan telah melebur dan tunduk ke dalam satu kesatuan sistem hukum nasional. Suatu isyarat bahwa, masyarakat adat selaku subyek hukum wajib tunduk dan mematuhi Segala bentuk peraturan perundang-undangan nasional yang berlaku di dalam proses kehidupan bemegara dan bermasyarakat.

Dalam Undang-Undang Nomor 41 Tahun 1999 tentang Kehutanan, juga disebutkan tentang ha-hak penguasaan masyarakat adat, yaitu sebagaimana disebutkan dalam Pasal 67 sebagai berikut:

1) Masyarakat hukum adat sepanjang menurut kenyataannya masih ada dan diakui keberadaannya berhak:

a. Melakukan pemungutan hasil hutan untuk pemenuhan kebutuhan hidup sehari-hari masyarakat adat yang bersangkutan;

b. Melakukan kegiatan pengelolaan hutan berdasarkan hukum adat yang berlaku dan tidak bertentangan dengan undang-undang; dan

c. Mendapatkan pemberdayaan dalam rangka meningkatkan * 10007 kesejahteraannya.

2) Pengukuhan keberadaan dan hapusnya masyarakat hukum adat sebagaimana dimaksud pada ayat (1) ditetapkan dengan Peraturan Daerah.

3) Ketentuan lebih lanjut sebagaimana dimaksud pada ayat (1) dan ayat (2) diatur dengan Peraturan Pemerintah.

Izin pemanfaatan hutan diberikan oleh Menteri, Gubemur, atau Bupati/Walikota sesuai dengan kewenangannya. Izin usaha pemanfaatan kawasan, jasa lingkungan, pemanfaatan hasil hutan kayu, pemanfaatan hasil hutan bukan kayu dan pemungutan hasil hutan kayu tidak dapat diberikan dalam areal hutan yang telah dibebani izin usaha pemanfaatan hutan. Izin pemungutan basil hutan bukan kayu dapat diberikan dalam areal hutan yang telah dibebani izin usaha pemanfaatan dengan komoditas yang berbeda Izin usaha pemanfaatan kawasan, jasa lingkungan, pemanfaatan hasil hutan kayu, pemanfaatan basil hutan bukan kayu dan pemungutan hasil hutan kayu dapat dipindahtangankan setelah mendapat persetujuan tertulis dari pemberi izin. Izin pemanfaatan hutan, arealnya tidak dapat dijadikanjaminan atau dijaminkan kepada pihak lain.

\section{PERANAN PEMERINTAH DALAM PELAKSANAAN REHABILITASI HUTAN MANGGROVE.}

\section{A. Peranan Pemerintah Kabupaten Aceh Besar Dalam Pelaksanaan Rehabilitasi Hutan Mangrove di Kabupaten Aceh Besar}

Kegiatan rehabilitasi hutan mangrove dimaksudkan untuk meningkatkan kelestarian ekosistem dan pengendalian kerusakan lingkungan pantai dan lautan serta meningkatkan kemampuan masyarakat pantai dalam mengelola kawasan pantai.

Sebagai salah satu ekosistem pesisir, hutan mangrove merupakan ekosistem yang unik dan khas. Ekosistem ini mempunyai fungsi ekologis dan ekonomis. Bahwa fungsi ekologis hutan manggrove antara lain: sebagai pelindung garis pantai, habitat, tempat mencari makan, tempat asuhan dan pembesaran, tempat pemijahan bagi aneka biota perairan, mencegah intrusi air laut, serta sebagai pengatur iklim mikro. Sedangkan fungsi ekonominya antara lain: penghasil keperluan rumah tangga, penghasil keperluan industri, dan penghasil bibit.

1. Peran Pemerintah dalam Pemetaan Lokasi Penanaman

Sebelum pelaksanaan kegiatan rehabilitasi lahan, dibutuhkan perencanaan awal terhadap identifikasi lahan yang 
akan direhabilitasi. Pemerintah Kabupaten Aceh Besar dalam melakukan rehabilitasi hutan manggrove di Kecamatan Mesjid Raya dan Kecamatan Baitussalam terlebih dahulu melakukan inventarisasi dan identifikasi lahan. Umumnya, lahan yang direhabilitasi di Kecamatan Mesjid Raya dan Kecamatan Baitussalam merupakan bekas lahan pertambakan intensif sebelum terjadinya tsunami. Karena terjadinya tsunami masyarakat pemilik tambak tersebut banyak yang menjadi korban tsunami, sehingga banyak lahan yang terlantar dan tidak terurus.

Lahan bekas pertambakan tersebut kembali di inventarisasi kepemilikannya oleh pemerintah melalui fasilitator pemerintah untuk melihat data fisik lahan untuk memulai kegiatan rehabilitasi. Inventarisasi kepemilikan ini juga bermanfaat untuk memberikan kontribusi kepada masyarakat pemilik dengan bibit mangrove yang akan ditanam setiap bibitnya dengan ukuran penanaman antara $1 \times 2$ meter dengan 1 x 3 meter. Rancangan yang dilakukan pemerintah dalam memetakan lahan yang akan direhabilitasi berdasarkan tata letak penanaman antara lain: luas dan letak calon lokasi penanaman, pembagian petak tanaman, luas dan letak calon lokasi persemaian, luas dan letak calon lokasi base camp dan letak saluran.

Pemetaan lokasi ini sangat penting untuk menunjang kegiatan rehabilitasi dilakukan, di samping untuk menghindari konflik di masyarakat oleh penggunaan lahan yang digunakan untuk persiapan sampai selesainya kegiatan rehabilitasi, juga dilakuk.an untuk menginformasikan lahan-lahan yang telah direhabilitasi.

2. Peran Pemerintah dalam Pendanaan

Dalam rehabilitasi hutan mangrove juga dibutuhkan dana yang besar, baik untuk pembibitan maupun untuk penanaman dan perawatan. Peranan pemerintah dalam pendanaan ini sangat dibutuhkan, walaupun dana tersebut tidak sepenuhnya berasal dari pemerintah.
Maka dalam kegiatan rehabilitasi hutan mangrove, pemerintah juga telah ikut berperan dalam pendanaan, walaupun dana dari pemerintah tersebut dirasakan belum mencukupi untuk aktivitas rehalitasi hutan mangrove sampai kesemua wilayah yang rusak.

3. Peran Pemerintah dalam Penyuluhan

Penyuluhan merupakan kegiatan yang dilakukan untuk memberikan penjelasan dan pengertian kepada masyarakat mengenai pelaksanaan rehabilitasi hutan mangrove yang diprogramkan. Melalui kegiatan ini diharapkan dapat memberikan penjelasan sekaligus pengertian dan pemaharnan kepada masyarakat, sehingga dapat menimbulkan persepsi yang baik dan dapat mendukung kelancaran program rehabilitasi hutan mangrove tersebut melalui partisipasi yang positif.

Penyuluhan ini dilakukan baik secara formal maupun tidak formal. Penyuluhan yang dilakukan secara formal dengan mengundang masyarakat melalui surat resmi dan penyelenggaraannya diatur pada tempat tertentu dan melibatkan masyarakat yang banyak. Penyuluhan formal ini umumnya telah ditentukan topik yang akan dibicarakan, seperti metode pembibitan, metode penanaman atau penyampaian format laporan pelaksanaan rehabilitasi hutan mangrove kepada kelompok masyarakat yang memperoleh dana bantuan program rehabilitasi tersebut. Penyuluhan tidak formal dengan melakukan pendekatan langsung kepada masyarakat yang menjalankan program rehabilitasi hutan mangrove dimulai dari aktivitas pembibitan, penanaman sampai kepada pemeliharaan baik secara kelompok maupun perseorangan di wilayah kerja pelaku kegiatan.

4. Peran Pemerintah dalam mengawasi dan evaluasi

Dalam pelaksanaan rehabilitasi hutan mangrove sangat dibutuhkan adanya proses pengawasan dan evaluasi. Hal ini dilakukan untuk melihat tingkat 
keberhasilan rehabilitasi hutan mangrove yang dilakukan.

5. Peran Pemerintah dalam Memfasilitasi Kegiatan Rehabilitasi Hutan Manggrove

Untuk kelancaran rehabilitasi hutan mangrove maka juga diperlukan fasilitas yang memadai. Sehingga peran pemerintah dalam memfasilitasi kegiatan rehabilitasi hutan mangrove juga merupakan kebutuhan yang tidak boleh ditunda.

Rutan mangrove merupakan jenis sumberdaya yang dapat diremajakan, yang berperan sebagai lindungan lingkungan dan juga sebagai penyedia barang dan jasa bagi keperluan hidup serta peningkatan kesejahteraan penduduk, khususnya penduduk pesisir, malalui pemanfaatan hasil hutan kayu dan bukan kayu termasuk pemanfaatanjasa lingkungannya. Oleh karena itu hutan mangrove harus dijaga dan dikelola dengan baik sehingga manfaatnya dapat maksimal dan lestari.

Peristiwa tsunami di Provinsi Aceh pada tanggal 26 Desember 2004 telah mengakibatkan sebagian besar hutan mangrove di wilayah pesisir Provinsi Aceh mengalami kerusakan yang cukup parah, dalam hal ini khususnya Kabupaten Aceh Besar. Hal tersebut telah mengakibatkan berkurangnya bahkan hilangnya manfaat dan peran dari ekosistem hutan yang bersangkutan. Dengan dernik:ian hutan mangrove tersebut harus direhabilitasi dalam rangka untuk memulihkan, mempertahankan dan meningkatkan fungsi hutan agar daya dukung, produkti:fitas clan peranannya dalam mendukung sistem penyangga kehidupan tetap terjaga.

Berdasarkan hasil penelitian dapat diketahui bahwa pemerintah Kabupaten Aceh Besar mengalami beberapa kendala dalam rangka merehabilitasi hutan mangrove, yaitu sebagai berikut:

1. Masih Kurangnya Tingkat Kesadaran Masyarakat

Kurangnya tingkat kesadaran masyarakat mengenai pentingnya hutan mangrove merupakan salah satu kendala yang dihadapi oleh pemerintah Kabupaten Aceh Besar dalam merehabilitasi hutan mangrove di wilayah tersebut.Mengenai hal tersebut diatas bahwa "tekanan penduduk dalam pemanfaatan sumberdaya mangrove menjadi salah satu faktor yang dapat menyebabkan kerusakan hutan mangrove, misalnya seperti pemanfaatan tegakan bakau untuk kayu arang, pemanfaatn daun dari beberapa jenis tumbuhan mangrove untuk pakan temak, serta pemanfaatan produk kayu dan non kayu serta jasa lingkungan yang dihasilkan oleh hutan mangrove.

Sedangkan responden lainnya mengatakan bahwa "dalam pelaksanaan rehabilitasi hutan manggrove tidak boleh mengalami benturan dengan sosio- kultural dan sistem norma sosial-budaya masyarakat setempat, atau sekurang- kurangnya tidak menimbulkan resistensi dari komunitas penduduk setempat atas rencana kegiatan rehabilitasi mangrove. Artinya, semakna dengan hal tersebut perlu ditumbuhkembangkan pemahaman, kesadaran, dan tanggung jawab seluruh elemen masyarakat untuk membangun sinergi dalam melaksanakan kegiatan serta menjaga kesinambungan kegiatan pengelolaan dan rehabilitasi hutan manggrove.

Gerakan swadaya masyarakat dalam penanganan masalah lingkungan dan khususnya masalah pengelolaan dan rehabilitasi hutan mangrove harus lebih dikembangkan.

Kurangnya tingkat kesadaran masyarakat menjadi salah satu kendala dalam merehabilitasi hutan manggrove, khususnya di Kabupaten Aceh Besar. Jadi dalam konteks ini, partisipasi masyarakat menjadi kata kunci sekaligus indikator keberhasilan dalam pelaksanaan kegiatan rehabilitasi hutan mangrove. Tingkat kesadaran dan juga gerakan swadaya masyarakat dalam penanganan atau perbaikan lingkungan hidup khususnya hutan mangrove masih harus terus untuk 
lebih dikembangkan lagi. Keterlibatan secara aktif dari masyarakat atau sering disebut partisipasi adalah sangat menentukan dalarn rangka keberhasilan mencapai tujuan pembangunan termasuk rehabilitasi hutan dan lahan.

2. Alih Fungsi Lahan Oleh Masyarakat

Adanya alih fungsi lahan mangrove menjadi lahan tambak serta beberapa bentuk pemanfaatan lainnya, telah menyebabkan rusaknya hutan mangrove. Dan alih fungsi lahan mangrove yang dilakukan oleh masyarakat tersebut juga telah menimbulkan kendala terhadap . rehabilitasi hutan mangrove.

Bahwa, "kegiatan rehabilitasi dengan sasaran lahan tambak masyarakat dan lahan- lahan yang berstatus hak milik dalam pelaksanaannya harus mempertimbangkan keinginan-keinginan pemilik tambak, dan ditambah lagi adanya sebagian pemilik tambak yang tidak mau melakukan penanaman mangrove di lahan milik mereka. Sehingga hal tersebut telah menyebabkan terkendalanya kegiatan rehabilitasi hutan mangrove.

Salah seorang petani tambak mengatakan bahwa "tambak yang dia kelola sekarang ini sebelumnya adalah lahan yang banyak ditumbuhi oleh pohon nipah dan bakau (mangrove), tetapi sekarang telah beralih fungsi menjadi tambak sepenuhnya dan tidak ada lagi pohon nipah atau bakau (mangrove) yang tumbuh. Dan dia juga -menambahkan bahwa sampai saat ini ia belum ada niat untuk menanam mangrove di lahan (tambak) miliknya tersebut. Menurutnya, keberadaan tumbuhan nipah atau bakau (mangrove) di dalam tambak miliknya tidak banyak menguntungkan, dan malah dapat menyebabkan sempitnya lahan tambak dengan pohon-pohon tersebut.

Sehubungan dengan hal tersebut diatas, maka sudah jelas bahwa aktivitas pembukaan hutan mangrove untuk pengembangan wilayah pemukiman atau untuk dijadikan tambak serta bentukbentuk pemanfaatan lainnya yang dapat merusak hutan mangrove merupakan suatu kendala yang dihadapi pemerintah dalam rangka merehabilitasi hutan mangrove. Karena kegiatan alih fungsi lahan tersebut dapat mengakibatkan berkurangnya bahkan hikangnya manfaat dan peran dari ekosistem hutan mangrove tersebut.

3. Kemiskinan (kondisi ekonomi masyarakat yang masih rendah)

Diketahui bahwa kondisi sosial ekonomi masyarakat juga sangat mempengaruhi upaya pengelolaan atau rehabilitasi hutan mangrove. Gangguan terhadapap mangrove sering dilakukan oleh masyarakat dikarenakan pendapatan mereka yang rendah serta altematif mata pencaharian yang terbatas.

Manggrove memiliki peran penting dalam melindungi pantai dari gelombang, angin dan badai, tetapi karena faktor kebutuhan akan ekonomi masyarakat sering melakukkan tindakan-tindakan yang dapat merusak hutan mangrove, misalnya seperti tindakan menebang pohon bakau (mangrove) untuk dijual yang kayunya dimanfaatkan untuk bahan bangunan, kayu bakar bahkan dapat dijadikan arang. Hal tersebut dilakukan karena faktor untuk memenuhi kebutuhan hidup sehari-hari dan masyarakat tidak sadar bahwa tindakan mereka tersebut telah merusak danjuga dapat menghabiskan komunitas hutan mangrove.

Masyarakat Kecamatan Baitussalam juga mengemukakan secara umum rusaknya hutan bakau terutama disebabkan oleh banyaknya pembangunan tambak, dan hal ini di perparah lagi dengan kondisi ekonomi masyarakat yang masih berpenghasilan rendah, sehingga telah mendorong mereka untuk memanfaatkan sumberdaya manggrove, seperti pemanfaatan produk kayu yang diperjualbelikan sebagai bahan-bahan bangunan. Kegiatan tersebut pada gilirannya telah mendorong perambahan hutan mangrove cenderung semakin meningkat.

Sedangkan masyarakat Kecamatan Mesjid Raya juga menjelaskan bahwa tidak 
adanya lapangan kerja dan timbulnya pengangguran juga merupakan sebagai faktor yang menyebabkan rusaknya hutan mangrove. Dan masyarakat yang tidak mencukupi kebutuhan hidupnya terpaksa akan menentukan pilihan pada perilalcu yang bertentangan dengan kehendak umum, misalnya melakukan perambahan hutan mangrove dengan tidak menghiraukan kondisi lingkungan tersebut.

Dari uraian tersebut diatas, dapat diketahui bahwa dampak kerniskinan telah menjadi hambatan dalam kegiatan rehabilitasi hutan manggrove. Sehingga pengelolaan dari rehabilitasi hutan mangrove juga sangat tergantung pada bagaimana mengakomodasi serta mengontrol kebutuhan masyarakat yang tinggal dan hidup di sekitar manggrove.

4. Terbatasnya Anggaran (minimnya anggaran)

Rehabilitasi hutan manggrove juga membutuhkan dana yang sangat besar, oleh karena itu dukungan anggaran juga sangat dibutuhkan. Sehingga dengan adanya anggaran yang memadai maka proses rehabilitasi hutan manggrove diharapkan akan berjalan dengan lancar. Namun demikian, dengan minimnya anggaran juga telah menjadi telah menjadi suatu kendala dalam merehabilitasi hutan mangrove di Kabupaten Aceh Besar.

5. Tidak Jelasnya Status Kepemilikan Lahan

Telah terbukti bahwa peranan manggrove bagi lingkungan sekitamya dirasakan sangat besar setelah berbagai dampak merugikan dirasakan diberbagai tempat akibat hilangnya manggrove. Untuk itu pengelolaan diperlukan pengelolaan hutan manggrove dengan baik, termasuk rehabilitasi terhadap hutan mangrove sehingga ekosistem hutan manggrove tetap terjaga Untuk merehabilitasi hutan manggrove tersebut dapat dilakukan diatas tanah negara ataupun tanah hak milik masyarakat.

Pada umumnya masyarakat setuju atas program rehabilitasi hutan mangrove, akan tetapi sebagian besar masyarakat tidak mau rehabilitasi hutan mangrove tersebut dilakukan diatas lahan-lahan milik mereka, Dengan demikian pemerintah harus melakukan kegiatan rehabilitasi tersebut sebagian besarnya diatas tanah yang bukan hak milik (tanah negara), akan tetapi akibat tsunami telah mengakibatkan hilangnya batas-batas pemilikan lahan clan telah menimbulkan ketidakjelasan status pemilikan atas lahan. Hal ini juga merupakan suatu kendala dalam merehabilitasi hutan mangrove, karena akan menyulitkan dalam penentuan lokasi rehabilitasi.Status kepemilikan lahan juga merupakan suatu kendala dalam merehabilitasi hutan manggrove, karena kondisi tersebut telah menyulitkan dalam penentuan lokasi rehabilitasi hutan manggrove di Kabupaten Aceh Besar.

Fungsi dan peranan hutan mangrove disadari semakin penting dalam upaya perlindungan ekosistem pesisir/pantai, serta bagi kepentingan sosial ekonomi masyarakat di kawasan pesisir, dan dalam kerangka ekologi wilayah, hutan mangrove berperan sebagai penyambung antar wilayah daratan dengan wilayah perairan laut. Manggrove memiliki kemampuan untuk menjaga kerusakan daratan akibat terjangan ombak/gelombang dan laju abrasi. Oleh karena yaitu, hutan manggrove harus dikelola dengan baik termasuk juga rehabilitasi sehingga manfaatnya dapat maksimal dan lestari.

Sebagaimana telah di uraikan sebelumnya, pemerintah Kabupaten Aceh Besar mengalami beberapa kendala dalam merehabilitasi hutan mangrove, yaitu: masih kurangnya tingkat kesadaran masyarakat, adanya alih fungsi lahan oleh masyarakat, kemiskinan, terbatasnya anggaran, dan tidak jelasnya status kepemilikan Iahan. Maka untuk mengatasi kendala tersebut, pemerintah Kabupaten Aceh Besar melakukan beberapa upaya sebagai berikut: 